\title{
Peer Teaching: A Pedagogic Method for Higher Education
}

\author{
Rajkumar Pillay, Mohammed Laeequddin
}

\begin{abstract}
Teaching the concepts of numerical courses is a significant challenge for engineering and the management students with innovative teaching pedagogy. Engineering and management education requires pedagogies that provide conceptual framework and that develop analytical and decision making skills to prepare students to face the complex problems. Class room dynamics add values to learning among students. Activities chosen by the professor can be central to many progressive learning experiences. Therefore, we experimented peer teaching methodology for post graduate management students (MBA) for teaching supply chain management concepts and application through a simulation game called "Beer game". The Beer Game players' experiences typical supply chain coordination problems, wherever information sharing and collaboration is missing. As a part of the peer group learning initiative, the senior batch students were encouraged to play the game with their juniors. Game demonstrates that communication gap and lack of collaboration can leads to an effect called "the bull whip effect" in the supply chain due to varying inventory levels at each link in the supply chain. Additionally, it was also intended for the students to develop their critical thinking, complex problem solving, leadership, negotiation, collaboration and communication skills in the process. Study results demonstrated a statistical significance in learning outcome, participant satisfaction. Learners results have shown a greater and high learning levels for the peer teachers. This peer teaching approach can be recommended to incorporated in teaching pedagogy for engineering and management students as one of the active learning method.
\end{abstract}

Keywords: Peer teaching, peer to peer learning, teaching by simulation models, peer group learning, peer teaching for higher education

\section{INTRODUCTION}

Teaching the concepts of numerical courses is a significant challenge for engineering and the management students with innovative teaching pedagogy. Engineering and management education requires pedagogies that provide conceptual framework and that develop analytical and decision making skills to prepare students to face the complex problems. Class room dynamics add values to learning among students. Activities chosen by the professor can be central to many progressive learning experiences. Most commonly used methods are: case study, simulation games, syndicates, group discussion, and role plays, experiential learning and near peer teaching. Pear teaching is a teaching methodology where senior students of similar backgrounds, separated by one to two years, teach each their juniors, mostly adopted by medical schools and found very successful [1]. Gunderson and Moore [2], stated that, "there

Revised Manuscript Received on October 05, 2019.

Rajkumar Pillay, Assistant Professor, Symbiosis Institute of Business Management, Hyderabad, Telangana, India.(E-mail:

rajkumar.pillay@sibmhyd.edu.in)

Mohammed Laeequddin, Associate Professor, Symbiosis Institute of Business Management, Hyderabad, Telangana, India. are also many other evidences that, peer learning and teaching is extremely effective for a wide range of goals, content, and students of different levels and personalities". According to West [3], Peer Assisted Learning (PAL), an activity supported learning provides positive benefits in terms of professional development for higher education students. Class room dynamics add values to learn among students. Activities chosen by the professor can be central to many progressive learning experiences. In the literature, we found studies on peer teaching in medical [1], English language [4], Higher education [5] but not many in engineering and management education. Therefore, we experimented peer teaching methodology for post graduate management students (MBA) more than 50\% students being engineering graduates, for teaching supply chain management concepts and application through a simulation game called "Beer game". The Beer Game players' experiences typical supply chain coordination problems, wherever information sharing and collaboration is missing. Game demonstrates that communication gap and lack of collaboration can leads to an effect called "the bull whip effect" in the supply chain due to varying inventory levels at each link in the supply chain. The Game was invented by Jay Forrester at MIT, in 1960's while working on behaviour of people on system structure. This game was chosen from the knowledge base of Harvard Publications. As a part of the peer group learning initiative, the senior batch students were engaged to play the game with their juniors, game scores resulting in a bull whip effect that teaches the importance of information flow in supply chain. The idea behind the peer teaching of the game was to provide an experiential learning simulation and also to provide a ground for peer group learning. The expected learning outcome of the game was providing an understanding on the bull whip effect in demand and supply of a supply chain. Additionally, it was also intended for the students to develop their critical thinking, complex problem solving, leadership, negotiation, collaboration and communication skills in the process. At the end of the game student's response was collected through a questionnaire to measure the learning outcome.

\section{OBJECTIVE OF THE EXPERIMENT}

1. Develop a new teaching pedagogy - peer teaching in engineering and management courses

2. Compare the learning out come between different batches and the peer teachers.

3. Analyse overall learning outcome of peers and their juniors study has demonstrated that, students learn in stimulated environment, class dynamics add value to the

Published By:

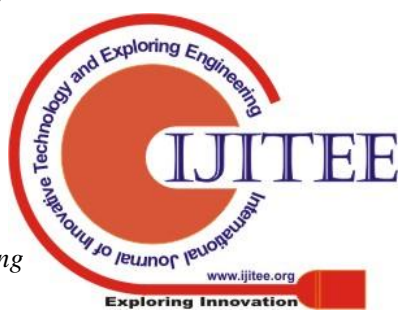




\section{Peer Teaching: A Pedagogic Method for Higher Education}

learning among students. Results have shown a greater and high satisfaction levels for the peer teachers.

This paper is structured as follows, next section presents a literature review and hypothesis development, section next to that presents research design and methodology, further section presents the study results and analysis and finally paper concludes with the observations and recommendations.

\section{LITERATURE REVIEW}

Goldschmid and Goldschmid [6] have identified five types of peer teaching techniques and published in a review after their vast experience in higher education.

1. Discussion groups: Students who have completed the course success fully and done well are used as teaching assistants to lead the group discussions, supplement lectures and correct the exam papers. led by student teaching assistants are used to supplement large lectures.

2. Proctors: Students act as course reporters to the course directors on how students are performing, problems with the course material, administer tests, work with individual students and give constructive feedback to on their test results.

3. Student groups - Student groups are organized as work groups to increase participation and work independently without the teacher, and periodically report to teacher.

4. Learning Cells: Students are formed as learning cells who read the material in advance, ask questions and answer them alternately. Review and give feedback on each other's work.

5. One-to-one help: Students counsel one to one outside the class room, review study habits of individuals, recommend approaches for improving grades, provide feedback on assignments,

According to Elise and Dallimore [7], there are three reasons that, student's engagement and participation in class improves learning in voluminous ways i). Class involvement increase engagement, in a group participation students are made to engage with one another to get access to information. ii). Secondly, verbal interaction may contain activities that help students remember what they have learnt and make sense of new learning. iii). Thirdly, the activity also helps to deepen the students understanding of what they are learning through hands-on practice and also application grounded learning opportunities designed by the professor.

Samantha [8] explored three ways of learning; "a). extending learning beyond the confines of the course, b).by modelling skills and attitudes useful in practice, and c). by allowing students to experience events that might later be confronted in practice are potential effect of in-class methods". He argued that, experiential teaching methods in the class room can have overwhelmingly positive learning outcome

The near peer teaching literature proves that, "there are benefits to the learner, the teacher and the faculty members" $[9,10]$. Erie et al., [11] reported that " $88 \%$ of their student teachers also benefited from teaching with scholarly output".

According to Davis [12], "students who are involved in 'group work' during class have been shown to develop a deeper understanding of the subject matter and increased problem-solving skills, the benefits of group work include engagement and development of team skills".

Cherif [5], proposed that, "the role of the classroom instructor in the peer teaching approach is to facilitate the group activity by

a). establish the related concepts, theories or topics that need to be studied and learned

b). monitoring the small group processes and

c). evaluating the final product in meaningful way".

Cherif [5] also found the following advantages of peer teaching approach,

"a). Students acquire and organise the data, to sense problems, and to develop concepts and convey their understanding. In management these skills are considered highly desirable in the job market and survival skills

b). Students are intellectually engaged in their own cognitive development through the analysis, synthesis, and evaluation of their own observations, data and communication

c). Psychologically, peer teaching gives the students a greater feeling of control over and responsibility for their learning, and involved learners learn better than passive learner.

d). Peer teaching provides an opportunity for students to experience being the leader in one domain. It gives them a sense of power and teaches them leadership skills".

As the saying goes, "He who teaches others, teaches himself," is very true, because the process of teaching in itself gives a deeper insight to the senior student with the subject taught.

Bargh and Schul [13] found that, "students in a teaching situation scored higher on an achievement test than those who did not teach. They suggested that preparing to teach someone else could produce a more highly organized cognitive structure". Hall et al., [9], found no difference between approachability when comparing senior medical student teachers with junior doctors. The research finding by Benware and Deci [14], suggested that "explaining to others may be more beneficial to the explainer when the material is complex, requiring integration or reorganization, than when the material is simple or straightforward".

From the literature review it was apparent that, peer teaching method can be an effective way of teaching the management concept involving numerical problems and emerging patterns in the decision making of managers under the uncertainties.

\section{METHODOLOGY}

The authors investigated the effect of incorporating peer teaching for semester I and II students of MBA operations management by their seniors from semester IV, who learnt the fundamental concepts of Supply Chain through "Beer game Simulation activity". The outcome of the activity was collected on 12 parameters through a questionnaire. 12 components were reduced in to two dimensions using factor analysis by extraction method of principal component

Blue Eyes Intelligence Engineering

\& Sciences Publication

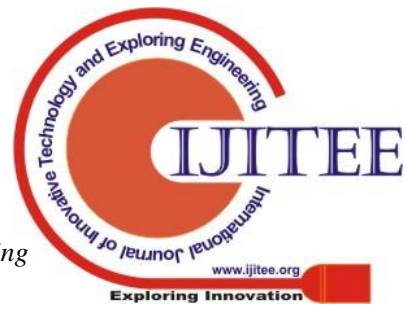


analysis and rotation method of varimax with Kaiser normalization. Further, reduced components were named as Facilitators centric and Students learning centric dimensions and established a relation between these two dimensions and overall satisfaction by using multiple regression analysis technique. Factor analysis as a statistical technique is data reduction technique used as a method for carrying a factor analysis to reduce the number of variables from the count of 12 to the count of two followed from the paper Orchestrating Teaching Business Statistics: A Methodology for Chi-square test [15]

The survey questionnaire was administered to all the participants and the peer teacher immediately after completing the session. In all 298 students responded from four batches of students and peers. The questionnaire was based on the understanding of supply chain concept and the bull whip effect in the demand and supply. Twenty questions were constructed to collect the relevant data for knowing the applicability of the pedagogy method for the management students. Seven questions were related to demographic information, twelve questions were teaching and learning centric satisfaction and one question to measure overall satisfaction of the pedagogy. A five point Likert scale for the questions related to teaching and learning centric was used which had responses from strongly disagree to strongly agree. Convenience sampling was used to gather the data from the responses who were taking supply chain management course in semester I and semester II either as a specialization or elective course. A Chi-square test was conducted for learning out of different batches, to test the sample adequacy, KMO and Bartlett's test was conducted, and to explore the relationship between the dependent variable "Overall satisfaction" and latent variables Facilitators centric, Student learning centric obtained from factor analysis, a multiple regression technique is used in SPSS 24.0 version

\section{A. Beer game simulation activity setting:}

A total of 68 team were formed in four semesters of the year 2018-19 and 2019-20 batches consisting of four students in each team labelled as retailer, wholesaler, distributor and manufacturer. 26 senior students were selected from the year 2017-18 and the year 2018-19 batch (approximately six seniors per batch) and engaged to act as customers, who releases the purchase orders (indent beer units) to their respective teams. One senior student was assigned for every three teams (12 students) who was acting as moderator of game while playing the role of a customer to raise the demand, and the demand flow through the chain, triggering orders at every level. The games were played on different dates depending upon the convenience of academic schedule and the availability of number of senior and junior students together.

\section{Description of the game}

Game begins with a constant customer demand for 100 beer units per week and the supply chain will be in a steady state for a while. Each member of the supply chain will have an inventory of 400 units. In every round each player follows the four steps:-
1. Check the number of units of beer supplied to him from his supplier.

2. Check the number of units of beer his customer has ordered.

3. Deliver as many units of beer as possible to his customer for customer's satisfaction

4. Decide number of units of beer to be received from his supplier to maintain the inventory and ensure that he has enough beer to meet expected customer orders.

The players are made aware of the following complications in the supply chain:

Delays - Supplier may not have enough inventor to deliver the demand of a player immediately. There can be a delay of at least one week from supplier to customer. A changed in order may delay at-least by two weeks.

Inventory carrying Costs - If a player has too many units of beer, its inventory costs will rise, with an inventory carrying cost of $\$ 0.5$ per week. Minimum inventory carrying cost is always $\$ 200$. Therefore, the minimum inventory level of beer units is 400 units, and the balance inventory by the end of the game should be 250 units preferably.

Backorder Costs - If the player cannot deliver ordered number of units of beer, there will be backorders penalty of $\$ 1$ per unit per week, therefore the target of back orders will be zero units.

At the end of the game each player's performance is measured on the following parameters.

1. Individual Supply Chain Cost - The accumulated cost of his inventory and backorders over time.

2. Total Supply Chain Cost - In the process player's may optimize individual cost at the expense of the other players in the supply chain.

Overall 298 students participated in the game, 152 from the batch 2018-19, and 146 learners from 2019-20 for the convenience of evaluation we have considered the peer teachers from the year 20

\section{B. Hypothesis development}

In order to evaluate the learning outcome of the peer teaching we developed the following hypothesis based on the literature review, objectives of the experiment and the peer teaching experiences of the previous batches.

H1. There is no difference between learning outcome of 2017 -18 batch peers teaching 2018-19 batch students and 2018 -19 peers teaching 2019-20 students

$\mathrm{H} 2$. There is no difference in the learning outcome of all the four batches of students

$\mathrm{H} 3$. There is a higher learning outcome for peers than students

H4. There is no difference between overall satisfaction of a pedagogic and the components measured in understanding the concepts 


\section{DATA COLLECTION, ANALYSIS AND INTERPRETAION \& RESULTS}

A survey questionnaire was administered immediately after every game to both the learns and trainers. Finding a substitute for beer bottles as raw material and the indent slips to be used in game was a major challenge. Being an offline activity, it was a daunting task to monitor all the teams and processes simultaneously. Flouting the norms of the game was yet another challenge. It was noted that, the layout of the setup of the activity can be modified from being played in an open environment to independent operating cubicles using technology. An environment of experiential learning was created to achieve the desired outcomes through active participation.

To test H1 (hypothesis 1) that, 'there is no difference between learning outcome of 2017 -18 batch peers teaching 2018-19 batch students and 2018-19 peers teaching 2019-20 students, a Chi-square test was conducted. As shown in table -1 , the Pearson's Chi-square, value of two tailed significance level is 0.939 and as per the Likelihood ratio, value of significance level is 0.937 . In both cases values of significance level was more than 0.05 , with the degree of freedom 3, hence H1was not rejected and understanding supply chain concept levels of these two batches had no difference and satisfied with the concepts in understanding with the simulation activity.

Table - 1 Chi-square Test

\begin{tabular}{|l|l|l|l|}
\hline & Value & Df & $\begin{array}{l}\text { Asymptotic } \\
\text { Significance } \\
\text { (2-sided) }\end{array}$ \\
\hline Pearson chi-square & 0.408 & 3 & 0.939 \\
\hline Likely hood ratio & 0.415 & 3 & 0.937 \\
\hline N of valid cases & 298 & & \\
\hline $\begin{array}{l}\text { a. 1 cells (12.5\%) have expected count less than 5. } \\
\text { The minimum expected count is 3.99 }\end{array}$ \\
\hline
\end{tabular}

To test the sample adequacy, KMO and Bartlett's test was conducted using SPSS 24 version. As shown in table -2 , the KMO statistic 0.883 that was 88.3 percentage, indicates the high proportion of variance in the variables that causes the underlying factors and it indicates that a factor analysis was an useful statistical technique for the study. The statistical significance score 0.000 against the Bartlett's test of Sphericity resulted that the correlation matrix was an identity matrix and it indicates small value less than 0.05 was the significant that a factor analysis was useful for the study.
Table -2 KMO and Bartlett's Test

\begin{tabular}{|c|c|c|c|c|}
\hline \multicolumn{4}{|c|}{$\begin{array}{l}\text { Kaiser - Meyer - Olkin Measure of } \\
\text { Sampling Adequacy }\end{array}$} & 0.883 \\
\hline \multirow{3}{*}{$\begin{array}{l}\text { Bartlett's } \\
\text { Sphericity }\end{array}$} & \multirow[t]{3}{*}{ Test } & \multirow[t]{3}{*}{ of } & $\begin{array}{l}\text { Approx. } \\
\text { Chi-Square }\end{array}$ & 5953.496 \\
\hline & & & $\overline{\mathrm{Df}}$ & 66 \\
\hline & & & Sig & 0.000 \\
\hline
\end{tabular}

To test the hypotheses $\mathrm{H} 2$ and $\mathrm{H} 3$, same written test was conducted for both the learners and peer teachers for 20 marks, their average score and standard deviations were tested. Table 2.1 provides the output from SPPS 24.0 which shows a significance difference in scores for peer teachers and learners.

Table 2.1 Group Statistics

\begin{tabular}{|c|c|c|c|c|c|}
\hline $\begin{array}{l}\text { Latent } \\
\text { name }\end{array}$ & variable & $\mathrm{N}$ & Mean & $\begin{array}{l}\text { Std. } \\
\text { Deviation }\end{array}$ & $\begin{array}{l}\text { Std. } \\
\text { Error } \\
\text { Mean }\end{array}$ \\
\hline \multirow[b]{2}{*}{$\begin{array}{l}\text { Score } \\
\text { obtained } \\
\text { after the } \\
\text { game }\end{array}$} & Learner & 272 & 17.1397 & 1.41512 & 0.08580 \\
\hline & Peer & 26 & 18.2308 & 0.51441 & 0.10088 \\
\hline
\end{tabular}

Bothe learners and Peers average scores were more than $85 \%$ which can be understood that all batches of learners and Peers had good learning outcome. Standard deviation of learners was 1.41512 which represents that the deviation of scores between the learners very less and more of similar scores. Hence it can be observed that learning outcome of learners are same. Again standard deviation of Peer group was 0.51441 which lesser than the learners and more similarity in the scores obtained between them. It signifies that learning outcome of Peers were also not different.

To test the hypothesis $\mathrm{H} 3$, independent samples T-test was conducted, as shown in table, 2.2, there was no significance difference between learning outcomes of learners and peers. The average scores of peers were more than the learners scores. Two tailed significance " $p$ " value under the assumptions of equal variances was 0.000 which is less than 0.05 level of significance, hence reject the null assumption that there is no significance difference between learners and peers i.e., peers had little better learning than learners because peers had a learning and teaching dimensions of learning. 
Table 2.2 - Independent Samples Test

\begin{tabular}{|c|c|c|c|c|c|c|c|c|c|c|}
\hline & \multirow{2}{*}{\multicolumn{2}{|c|}{\begin{tabular}{|lr}
\multicolumn{2}{|c|}{ Levene's } \\
Test & for \\
Equality & of \\
Variances & \\
\end{tabular}}} & \multirow{2}{*}{\multicolumn{7}{|c|}{ t-test for Equality of Means }} \\
\hline & & & & & & & & & & \\
\hline & & \multirow[t]{2}{*}{$\mathrm{F}$} & \multirow[t]{2}{*}{ Sig } & \multirow[t]{2}{*}{$\mathrm{t}$} & \multirow[t]{2}{*}{ df } & \multirow{2}{*}{$\begin{array}{l}\text { Sig. } \\
(2- \\
\text { tailed })\end{array}$} & \multirow{2}{*}{\begin{tabular}{l}
\multicolumn{1}{c}{ Mean } \\
Differenc \\
e
\end{tabular}} & \multirow{2}{*}{$\begin{array}{l}\quad \text { Std. } \\
\text { Error } \\
\text { Difference }\end{array}$} & \multicolumn{2}{|c|}{\begin{tabular}{|l}
\multicolumn{2}{|c|}{$95 \%$} \\
Confidence \\
Interval of the \\
Difference
\end{tabular}} \\
\hline & & & & & & & & & Lower & Uppe \\
\hline \multirow{2}{*}{$\begin{array}{r}\text { Score } \\
\text { obtained } \\
\text { after the } \\
\text { game }\end{array}$} & \begin{tabular}{|c|}
\multicolumn{1}{c}{ Equal } \\
variances \\
assumed
\end{tabular} & $32^{33.6}$ & $00^{0.0}$ & 3.902 & 296 & $0^{0.00}$ & $\begin{array}{c}- \\
1.09106\end{array}$ & 0.27964 & $\begin{array}{c}- \\
1.64140\end{array}$ & $\begin{array}{c}- \\
0.54073\end{array}$ \\
\hline & \begin{tabular}{|l}
\multicolumn{1}{|c}{ Equal } \\
variances \\
not \\
assumed
\end{tabular} & & & $\begin{array}{c}- \\
8.238\end{array}$ & $\begin{array}{l}70 . \\
832\end{array}$ & $0^{0.00}$ & $\begin{array}{c}- \\
1.09106\end{array}$ & 0.13244 & $\begin{array}{c}- \\
1.35515\end{array}$ & $\begin{array}{c}- \\
0.82698\end{array}$ \\
\hline
\end{tabular}

Table 3, displays the components participated in factor analysis, Eigen value of components and the total score obtained by adding Eigen values of the components and the construction of underlying dimensions Facilitators centric and Students learning centric. The variance explained by initial solution, extracted components and rotated components shows initial Eigen values, the total column gives the Eigen value or an amount of variance in the original variables accounted by each component, Component value of the total column exceeds one is considered to be as the reduced or latent components for further analysis as they are accounting for better variance. The percentage value of variance column gives the ratio expressed as percentage of the variance accounted by each component to the total variance in all the variables. In the extracted sums of the squared loading, cumulative percent of 89.61 of the variability in the original twelve variables are explained so, considerably these twelve variables complexity can be reduced in to two latent variables or dimensions which are named as Teaching centric and Student learning centric. Only 11.39 percent of the information loss, hence the rotation maintains the cumulative percentage of variation explained by extracted components. Large changes in the individual total suggest the rotated component matrix shall be easier to interpret the un-rotated matrix.

Table - 3 Factor Analysis of Variables

\begin{tabular}{|c|c|c|c|}
\hline Dimensionality name & Components & $\begin{array}{ll}\text { Eigen } & \text { value } \\
\text { Score } & \end{array}$ & Total score \\
\hline \multirow{8}{*}{$\begin{array}{l}\text { Learners Perspective (class of } \\
2020 \text { and 2021) }\end{array}$} & The objectives of the game are clearly defined & 0.882 & \multirow{8}{*}{8.77} \\
\hline & $\begin{array}{l}\text { The course helped me in improving } \\
\text { understanding the supply chain process }\end{array}$ & 0.888 & \\
\hline & $\begin{array}{l}\text { Team work and interaction was promoted } \\
\text { amongst the students }\end{array}$ & 0.912 & \\
\hline & The game was organized and easy to follow & 0.919 & \\
\hline & $\begin{array}{l}\text { The game was relevant to real world issues of } \\
\text { supply chain and the same was made apparent }\end{array}$ & 0.867 & \\
\hline & $\begin{array}{l}\text { The instructors were enthusiastic about teaching } \\
\text { the SCM concepts through the game }\end{array}$ & 0.915 & \\
\hline & Focus of the game was on experiential learning) & 0.880 & \\
\hline & $\begin{array}{l}\text { Pear group moderators are knowledgeable about } \\
\text { the game }\end{array}$ & 0.894 & \\
\hline \multirow[t]{3}{*}{ Trainers perspective } & $\begin{array}{l}\text { The pear group moderators made easy in } \\
\text { learning SC concepts }\end{array}$ & 0.912 & \multirow{3}{*}{1.976} \\
\hline & $\begin{array}{l}\text { The time allotted for learning the concepts are } \\
\text { met }\end{array}$ & 0.903 & \\
\hline & The class room and facilities are adequate & 0.920 & \\
\hline
\end{tabular}


To explore the relationship between the dependent variable "Overall satisfaction" and latent variables Facilitators centric, Student learning centric obtained from factor analysis, a multiple regression technique is used in SPSS 24.0 version. $\mathrm{R}$ value 0.901 from the following Model summary, table - 4 indicates a high degree of correlation between target variable and predictor variables. $\mathrm{R} 2$ value 0.812 indicates the percentage of variance explained in dependent variable due to predictor variables which is very large.

Table - 4 Model Summary

\begin{tabular}{|l|l|l|l|l|}
\hline Model & R & $\begin{array}{l}\text { R } \\
\text { Square }\end{array}$ & $\begin{array}{l}\text { Adjusted } \\
\text { R Square }\end{array}$ & $\begin{array}{l}\text { Std.Error } \\
\text { of Estimate }\end{array}$ \\
\hline 1 & $0.901^{\mathrm{a}}$ & 0.812 & 0.812 & 0.39929 \\
\hline
\end{tabular}

From the table-5 ANOVA report shows, how well the regression equation fits the data, i.e. predicts the data. ANOVA table indicates that the regression model predicts the dependent variable significantly well. Because in the Regression row under the significance value is 0.000 which is less than 0.05 is the evidence to reject the null hypothesis between overall satisfaction of a pedagogic and components measured in understanding the concepts. That means there was an effect on overall satisfaction by the pedagogic adopted. The coefficients table provided with the necessary information to predict overall satisfaction of the pedagogic from facilitators centric and students learning centric. Significant values of predictors are less than 0.05 which determines that there is a significant relation between dependent and predictors by rejecting the null hypothesis that there is no significance difference between overall satisfaction and latent variables. Furthermore, we can use the values in the $\mathrm{B}$ column under the unstandardized coefficients to represent the regression equation as follows: -

Overall satisfaction of the pedagogic $=1.653+(0.780)$ Trainers perspective $+(0.275)$ Learners perspective.

\begin{tabular}{|c|c|c|c|c|c|c|}
\hline \multicolumn{7}{|c|}{ Table - 5 ANOVA } \\
\hline \multicolumn{2}{|c|}{ Model } & $\begin{array}{l}\text { Sum of } \\
\text { Squares }\end{array}$ & Df & $\begin{array}{l}\text { Mean } \\
\text { Square }\end{array}$ & $\mathrm{F}$ & Sig. \\
\hline \multirow[t]{3}{*}{1} & $\begin{array}{l}\text { Regressio } \\
n\end{array}$ & 200.217 & 2 & 100.109 & $\begin{array}{l}627.9 \\
05\end{array}$ & $0.000^{\mathrm{b}}$ \\
\hline & Residual & 46.395 & 291 & 0.159 & & \\
\hline & Total & 246.612 & 293 & & & \\
\hline \multicolumn{7}{|c|}{$\begin{array}{l}\text { a. Dependent variable: overall learning from peer group } \\
\text { is satisfied }\end{array}$} \\
\hline \multicolumn{7}{|c|}{$\begin{array}{l}\text { b. Predictors (Constant), Facilitators centric, Student } \\
\text { learning centric }\end{array}$} \\
\hline
\end{tabular}

\section{CONCLUSIONS}

Teaching the concepts of numerical courses is a significant challenge for engineering and the management students with innovative teaching pedagogy. Engineering and management education requires pedagogies that provide conceptual framework and that develop analytical and decision making skills to prepare students to face the complex problems. Class room dynamics add values to learning among students. Activities chosen by the professor can be central to many progressive learning experiences. Therefore, we experimented peer teaching methodology for post graduate management students (MBA) for teaching supply chain management concepts and application through a simulation game called "Beer game". Study results demonstrated a statistical significance in learning outcome scored by a written test and the participant satisfaction survey showed a higher learning and greater satisfaction of the participants. Simulated game has demonstrated a total engagement of the participants and the peer teacher for 90 minutes without distractions and the game was ended with the excitement and competitive spirit between the teams and also a WOW effect. Peer teaching and simulated game methodology is strongly suggested as one of the outcome based learning activity for engineering and management students.

\section{REFERENCES}

1. Bulte, C., Betts, A., Garner, K. \& During, S. (2007), "Student teaching: views of student near-peer teachers and learners". Medical Teacher. Vol.29, No.6, pp. 583590

2. Gunderson.DE, and Moore. J. D (2008), "Group Learning Pedagogy and Group Selection", Internationa Journal of Construction Education and Research, Vol.4, No.1, pp. 34-45

3. West, J. (2017), "Becomming an Effective Peer Assisted Learning (PAL) Leader". Journal of Geography in Higher Education, Vol.3, pp. 459-465.

4. Bradford-Watts, K. (2011), "Students teaching students? Peer teaching in the EFL classroom in Japan" THE LANGUAGE TEACHER: Vol.35, No.5, September / October issue, pp. 31-35

5. Cherif. HA. (1993), "Peer Teaching in Small Group Setting" Forward to Excellence, Vol.1, pp.5-6

6. Goldschmid, Barbara, and Goldschmid, Marcel L. (1976), "Peer Teaching in Higher Education: A Review." Higher Education, Vol. 5, No.1, pp. 9-33.

7. Elise J. Dallimore, P. J. (2017, March 27), Faculty Focus. Retrieved from https://www.facultyfocus.com/articles/effective-teachingstrategies/students-learn-participation-class-discussion/

8. Samantha, W. (2011), "Reflections on Experiencial Teaching Methods: Linking the class room to practice". Journal of Teaching in Social Work,Vol. 31, No.5, pp. 493-504

9. Hall S, Stephens J, Andrade T, Davids J, Powell M, Border S. (2014), "Perceptions of junior doctors and undergraduate medical students as anatomy teachers: investigating distance along the near-peer teaching spectrum" Anat Sci Educ, Vol 7, pp. 242-247.

10. Lockspeiser T, O'Sullivan P, Teherani A, Muller J. (2008), "Understanding the experience of being taught by peers: the value of social and cognitive congruence" Adv Health Sci Educ Vol.13, No.3, pp.361-372.

11. Erie A, Starkman. S, Pawlina W, Lachman N. (2013), "Developing medical students as teachers: an anatomybased student-as-teacher program with emphasis on core 
teaching competencies". Anat Sci Educ, Vol.6, No.6, pp.385-392.

12. Davis, B. (2009). Tools for teaching. (2nd ed.) CA: Jossey-Bass.

13. Bargh, John A., and Schul, Yaakov. (1980), "On the Cognitive Benefits of Teaching." Journal of Educational Psychology, Vol. 72, No. 5, pp.593 -604.

14. Benware, Carl A., and Deci, Edward L. (1984), "Quality of Learning with an Active Versus Passive Motivation Set." American Educational Research Journal, Vol 21, No. 4, pp. 755-66.

15. Rajkumar Pillay, S. (2017), "Orchestrating Teaching Business Statistics: A Methodology for Chi-square Test". International Journal of Applied Business and Economics Research,Vol.15

\section{AUTHORS PROFILE}

First Author Professor Rajkumar Pillay's academic career now spans more than 15 years, during which he has published several research papers and articles in national and international journals. His research areas include, teaching pedagogy in the faculty of Business

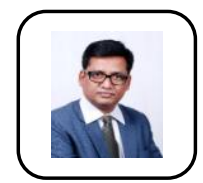
ced Statistics, Data Analysis Methods and Supply Chain Statistics, Advanced Statics with special reference to simulation models in operations.

His significant publications are (1) Revisiting Servant Leadership: An Empirical study in Indian Context and (2) Teaching Concepts of Probability: A case Methodology for B-Schools, and has 51 citations with "h-index and I10 index".

Second Author Dr. Mohammed Laeequddin is a Ph.D

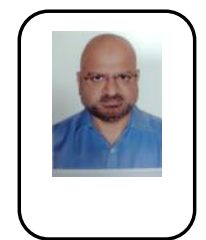
from Indrapratha University, Delhi. He completed his $\mathrm{Ph} . \mathrm{D}$ in the area of trust in Supply Chain Partners Relationship. He did his M.tech in Industrial Engineering and Management from JNTU Hyderabad and B.Tech (Mech.Engg.) from NIT Warangal. He has more than 25 years of Industry experience in operations management, mostly in the Middle-east countries. He has number of research publications in International Journals like Supply Chain Management: An international Journal, Management Decision, Measuring Business Excellence, Journal of Management Development, International Journal of Case Studies in Management. 